\title{
Evaluation of Genetic Diversity of Carambola (Carambola averrhoa L.) in Arunachal Pradesh, India
}

\author{
Rebica Padun and S.R. Singh*
}

College of Horticulture \& Forestry, Central Agricultural University, Pasighat-791 102, Arunachal Pradesh, India

*Corresponding author

\section{A B S T R A C T}

An extensive survey was conducted in different District (Upper Siang, West Siang and East Siang) of Arunachal Pradesh during 2015-17 to study the genetic diversity of

\section{Keywords}

Carambola,

Physico-chemical character and SDSPAGE

Article Info

Accepted:

24 January 2018

Available Online:

10 February 2018 carambola and to identify superior genotypes having sweet in taste based on the descriptor of NBPGR carambola. The experimental result showed that individual fruit weight ranged from $83.53 \mathrm{~g}\left(\mathrm{P}_{20}\right)$ to $300.00 \mathrm{~g}\left(\mathrm{P}_{14}\right)$; fruit diameter $4.07 \mathrm{~cm}\left(\mathrm{P}_{5}\right)$ to $9.13 \mathrm{~cm}\left(\mathrm{P}_{14}\right)$; fruit length $6.83 \mathrm{~cm}\left(\mathrm{P}_{4}\right)$ to $15.93 \mathrm{~cm}\left(\mathrm{P}_{14}\right)$; juice content $25.00 \mathrm{ml}\left(\mathrm{P}_{4}\right)$ to $61.67 \mathrm{ml}\left(\mathrm{P}_{14}\right)$; seed/fruit $2.00\left(\mathrm{P}_{1}\right)$ to $4.67\left(\mathrm{P}_{12}\right)$; fruit yield $84.33 \mathrm{~kg}\left(\mathrm{P}_{4}\right)$ to $185.00 \mathrm{~kg} /$ tree $\left(\mathrm{P}_{8}\right)$; TSS 5.03 $\left(\mathrm{P}_{12}\right)$ to $14.97{ }^{0} \mathrm{Brix}\left(\mathrm{P}_{11}\right)$; oxalic acid $0.01 \%\left(\mathrm{P}_{2}, \mathrm{P}_{3}, \mathrm{P}_{5}, \mathrm{P}_{7}, \mathrm{P}_{8}, \mathrm{P}_{14}\right.$ and $\left.\mathrm{P}_{18}\right)$ to $0.35 \%\left(\mathrm{P}_{9}\right)$; ascorbic acid $25.00\left(\mathrm{P}_{17}\right)$ to $68.00 \mathrm{mg} / 100 \mathrm{~g}\left(\mathrm{P}_{9}\right)$; acidity $0.08 \%$ to $1.22 \%$; reducing sugar $3.20 \%\left(\mathrm{P}_{3}\right)$ to $11.93 \%\left(\mathrm{P}_{11}\right)$; total sugars $3.40 \%\left(\mathrm{P}_{3}\right)$ to $12.80 \%\left(\mathrm{P}_{11}\right)$ and shelf life 10.67 days $\left(\mathrm{P}_{10}\right)$ to 14 days $\left(\mathrm{P}_{17}\right)$. Based on the results obtained from the present investigation, it can be concluded that, selected carambola genotypes exhibited noticeable variation in the morphological, biochemical and yield characters. SDS-PAGE analysis also showed considerable variation in band number of protein which ranged from 14-38. Thus, these findings illustrated the usefulness of physic-chemical characterization and biochemical marker as a tool for the genetic diversity evaluation in carambola.

\section{Introduction}

Carambola (Averrhoa carambola L.), also known as star fruit, is a curious attractive underutilized fruit of warm and sub-tropical areas of the world which belong to the family Oxalidaceae. The fruit has distinctive ridges running down its sides (usually five but can sometimes vary); in cross-section, it resembles a star, hence its name. The entire fruit is edible and is usually eaten as raw. They may also be used in cooking as substitute of tamarind
(Singh et al., 1990). It is believed that it may have originated from Sri Lanka or Moluccas, Indonesia, but has been cultivated in the Indian Subcontinent and South-East Asian countries for hundreds of years. They are cultivated commercially in Southeast Asia, Southern China, Taiwan and Florida. They are also grown in Nicaragua, Costa Rica, Panama, Colombia, Ecuador, El Salvador, Peru, Brazil, Jamaica, Haiti, the Dominican Republic, Puerto Rico, Trinidad, Mexico, Guyana and parts of Africa (Morton, 1987). In India, they 
are mainly confined in the homestead garden (Chadha, 2013). The fruit is about 5 to 15 centimeters (2 to 6 inches) in length and is oval shaped. It usually has five prominent longitudinal ridges, but in rare instances it can have as few as four or as many as eight. In cross section, it resembles a star. The skin is thin, smooth and waxy. It turns a light to dark yellow when ripe having climacteric nature. The flesh is translucent and light yellow to yellow in color. Each fruit can have 10 to 12 flat light brown seeds having about 6 to $13 \mathrm{~mm}$ ( 0.25 to $0.5 \mathrm{in})$ in width and enclosed in a gelatinous aril. Once removed from the fruit, they lose viability within a few days as they are recalcitrant in nature (Crane, 1994). The fruit of carambola is a rich source of reducing sugars, ascorbic acid and minerals such as K, Ca, Mg and P (Haick, 1952). Ripe fruits of sweet form of carambola contain both oxalic acid $(0.16 \%)$ and malic acid $(0.06 \%)$, whereas fruits of sour form contain only oxalic acid in quantities ranging from $1.0 \%$ in unripe fruits to $0.51 \%$ in ripe ones. Sugars present in both type consist largely of glucose with moderate quantities of fructose and traces of sucrose and vitamin C content is also high (Lewis et al., 1954). Samson (1986) stated that the fruits contain several amino acids including serine, glutamic acid and alanine. It is also a potent source of both primary and secondary polyphenolic antioxidants (Shui and Leong, 2004). Besides, Singh et al., (2014) also reported that ripe fruit pulp of carambola along with little common salt is eaten against jaundice, bleeding piles and for washing utensils. Also, the crushed leaves have also been for curing chicken pox, ring worm and scabies and its root extract is used as an antidote for poisoning.

Arunachal Pradesh has a rich diversity of carambola and there is availability of different size and fruit quality having sour and sweet taste. The superior genotypes of carambola developed through selection from countries like Thailand and Malaysia are sweet in taste and have TSS ranging from $8-15^{\circ}$ Brix (Ray, 2002). Similar superior genotypes of sweet type carambola are also available in Arunachal Pradesh but still unexploited as they are grown in the homestead garden or wild form in the forest. Locally sweet genotypes known as 'Rohodoi' and sour genotypes as 'Kordoi' are grown in homestead garden. However, research in diversity of carambola in this region for the evaluation of superior genotype has not yet been documented. Besides, there is lack in the crop improvement for this important underutilized fruit crop in India. Further, there is a need for multiplication of the superior genotypes of sweet type of carambola found in this region as it might be liable to extinction if there is no documentation and multiplication for such superior genotypes. Looking at the importance of this fruit, the demand for its planting material is also increasing due to its medicinal and nutritional properties. Moreover, documentation of the genetic diversity to evaluate promising genotypes found in Arunachal Pradesh has also not been attempted. Therefore, keeping in view of the above facts, the present experiment was carried out in three districts of Arunachal Pradesh (East, West and Upper Siang district) for the exploration of superior genotypes of carambola having sweet taste and heavy bearing habit.

\section{Materials and Methods}

The survey, selection and identification were specifically carried out in East Siang, Upper Siang and West Siang districts of Arunachal Pradesh. The geographical location of this area is situated in between $\mathrm{N} 27^{\circ} 56.629^{\circ}-\mathrm{N}$ $28^{\circ} 10.402$ latitude and E $095^{\circ} 07.233^{`}-\mathrm{E}$ $095^{\circ} 26.520^{\prime}$ longitudes with an altitude of 132-393 meter above the mean sea level. The experimental materials for the present investigation comprised of 20 selected 
genotypes of carambola having sweet taste to evaluate the superior genotype from it. The sources of 20 carambola were $\mathrm{P}_{1}, \mathrm{P}_{10}, \mathrm{P}_{11}, \mathrm{P}_{17}$ from Pasighat, East Siang district, $\mathrm{P}_{2}, \mathrm{P}_{5}, \mathrm{P}_{6}, \mathrm{P}_{7}$, $\mathrm{P}_{8}$ from Ngorlung, East Siang distrct, $\mathrm{P}_{3}$ and $\mathrm{P}_{4}$ from Sille, East Siang, $\mathrm{P}_{9}, \mathrm{P}_{12}, \mathrm{P}_{13}, \mathrm{P}_{15} \mathrm{P}_{16}$ from Geku, Upper Siang, $\mathrm{P}_{14}$ from Kiyit, East Siang and $\mathrm{P}_{19}, \mathrm{P}_{20}$ from Aalo, West Siang. Survey work was carried out in different districts of Arunachal Pradesh. Selection and identification of superior genotype were done following the NBPGR carambola descriptor. The basic parameters and physico-chemical characters of carambola were recorded based on the NBPGR carambola descriptor for identification of superior genotypes. Estimation of protein was done as Lowry's method (1951) and Polyacrylamide gel electrophoresis (PAGE) in presence of denaturing agent (SDS) was carried out as per procedure described by Laemmli (1970) with some modifications with the $10 \%$ Acrylamide Separating Gel for the diversity analysis among the selected genotypes of carambola.

\section{Results and Discussion}

\section{Variability in physical characters}

There were wide variations among different carambola genotypes with respect to physical characters of the fruit. The fruit length parameter varied from $6.83 \mathrm{~cm}$ in $\mathrm{P}_{4}$ to 15.93 $\mathrm{cm}$ in $\mathrm{P}_{14}$ and the average fruit length was 8.81 $\mathrm{cm}$. In contrast Chadha (2013) obtained more narrow range of fruit length $(12-15 \mathrm{~cm})$. In this regard Narain et al., (2001) found that the average length of the fruit was $7.92 \mathrm{~cm}$. In respect of fruit diameter, significant variations were seen among the fruit of different genotypes. The observed values ranged from $4.07 \mathrm{~cm}$ in $\mathrm{P}_{5}$ to $913 \mathrm{~cm}$ in $\mathrm{P}_{14}$. Average fruit diameter observed by Narain et al., (2001) was $5.24 \mathrm{~cm}$ whereas the average fruit diameter of present finding is $5.51 \mathrm{~cm}$. The data obtained on fruit rib thickness showed significant differences among different genotypes. The thinness rib was recorded in $\mathrm{P}_{7}$ $(1.3 \mathrm{~cm})$ while the thickest rib was in $\mathrm{P}_{5}(1.83$ $\mathrm{cm})$ and $\mathrm{P}_{14}(1.83 \mathrm{~cm})$. The average fruit rind thickness was $1.53 \mathrm{~cm}$. Similarly, Narain et al., (2001) reported that the fruit rib thickness varies from $0.19-1.69 \mathrm{~cm}$.

The data obtained on fruit rib length showed significant differences among different genotypes. The fruit rib length range from $1.40 \mathrm{~cm}$ in $\mathrm{P}_{18}$ to $2.33 \mathrm{~cm}$ in $\mathrm{P}_{14}$. The average fruit rib length was $1.92 \mathrm{~cm}$. The fruit weight varied significantly and ranged from $83.53 \mathrm{~g}$ to $300 \mathrm{~g}$. The fruit of genotype $\mathrm{P}_{14}$ recorded the maximum fruit weight $(300 \mathrm{~g})$ followed by $\mathrm{P}_{2}(170.03 \mathrm{~g})$. On the other hand, the minimum fruit weight $(83.53 \mathrm{~g})$ was recorded in genotypes $\mathrm{P}_{20}$ followed by $\mathrm{P}_{3}(90.03 \mathrm{~g})$ and $\mathrm{P}_{5}$ $(90.03 \mathrm{~g})$. The mean value was $122.46 \mathrm{~g}$. Narain et al., (2001) reported that fruit weight ranged from 20.26-57.32 $\mathrm{g}$ which is contrast to the present investigation.

The fruit yield of different carambola genotypes ranged from $84.33 \mathrm{Kg}$ per year per plant to $185 \mathrm{Kg}$ per plant per year with the average yield of $123.5 \mathrm{Kg}$ per plant per year. Genotype $\mathrm{P}_{8}$ was found to be highest $(185 \mathrm{Kg}$ per plant per year) followed by $\mathrm{P}_{9}(165 \mathrm{Kg}$ per plant year) and lowest was recorded in $\mathrm{P}_{4}$ (84.33 Kg per plant per year). Similarly, Goenaga (2007) also found that maximum yield was $36,060 \mathrm{Kg}$ per ha and minimum yield was recorded $23,490 \mathrm{Kg}$ per ha in the carambola tree.

Investigation reported that there were two flushes of flowering in a year, a number of fruits per plant were observed among the selected carambola. The maximum number of fruit per tree of 2250 was recorded by $\mathrm{P}_{8}$, which was followed by $\mathrm{P}_{9}$ (2000). The least number of fruit per tree of 400 was recorded in $\mathrm{P}_{14}$. Goenaga (2007) reported that number of fruit per ha was 258761 fruit per ha. 
The number of seeds per fruit significantly differed among the genotypes and ranged from 2 to 4.67 with the average seeds content of 3.42. Minimum number seed was found in $P_{1}$ (2). Narain et al., (2001) reported that number of seeds per fruit ranged from 1.83 to 4.97 which are almost similar to the present finding. Besides, Bhaskar and Shantaram (2013) also reported that number of seed per fruit range from 0.87 to 5.35. The seed colour of all selected genotypes of carambola was found to be brown. Similarly, Gheewala et al., (2012) also reported that seed colour of the fruit is brown. The average weight of 10 seeds among the different genotype ranged between $0.56 \mathrm{~g}$ in $\mathrm{P}_{1}$ and $0.76 \mathrm{~g}$ in $\mathrm{P}_{17}$ with the average value of $0.66 \mathrm{~g}$. In this regard, Narain et al., (2001) found that average weight of 10 seeds range from $0.37-0.70 \mathrm{~g}$ which is almost similar to present findings.

The fruit pedicel of selected genotypes of carambola was found to be brown in colour. The data obtained on fruit pedicel length showed significant differences among different genotypes. The pedicel length range from $\mathrm{P}_{16}(3.87 \mathrm{~cm})$ to $\mathrm{P}_{2}(5.13 \mathrm{~cm})$ followed by $\mathrm{P}_{8}(4.93 \mathrm{~cm})$. The average fruit pedicel length was $4.36 \mathrm{~cm}$. Pedicel diameter of the selected genotypes of carambola was found to be insignificant. With regard to the fruit juice content, it significantly varied among different genotypes and ranged from $25 \mathrm{ml}$ to $61.67 \mathrm{ml}$ with the mean value of $36.39 \mathrm{ml}$. The highest fruit juice content recorded was in $\mathrm{P}_{14}$ with $61.67 \mathrm{ml}$ followed by $\mathrm{P}_{18}(49.67 \mathrm{ml})$ and $\mathrm{P}_{8}$ $(47.33 \mathrm{ml})$. Juice content of $\mathrm{P}_{4}$ was recorded lowest (25 ml) (Table 1).

\section{Variability in chemical characters of fruit}

The observed data of different genotypes showed significant variation for TSS. The observed value ranged from $5.03{ }^{0}$ Brix in $\mathrm{P}_{12}$ to $14.97{ }^{0}$ Brix in $\mathrm{P}_{11}$ with the mean value of $7.28{ }^{0}$ Brix. In this regard, Watson et al., (1988) estimated that the TSS content of the carambola ranged from $5-13^{0}$ Brix.

The oxalic acid content of different selected genotypes of carambola, Oxalic acid content showed varied significance which ranged from $0.01 \%\left(\mathrm{P}_{2}, \mathrm{P}_{3}, \mathrm{P}_{5}, \mathrm{P}_{7}, \mathrm{P}_{8}, \mathrm{P}_{14}\right.$ and $\left.\mathrm{P}_{18}\right)$ to $0.35 \%$ $\left(\mathrm{P}_{9}\right)$. In this regard, Watson et al., (1988) reported that the oxalic acid content of carambola ranged from $0.04-0.07 \%$ in $100 \mathrm{~g}$ and Arrexels et al., (2001) also reported that oxalic acid content is less in ripe fruit (Table 2).

Fig.1 SDS-PAGE banding pattern among 20 genotypes of carambola

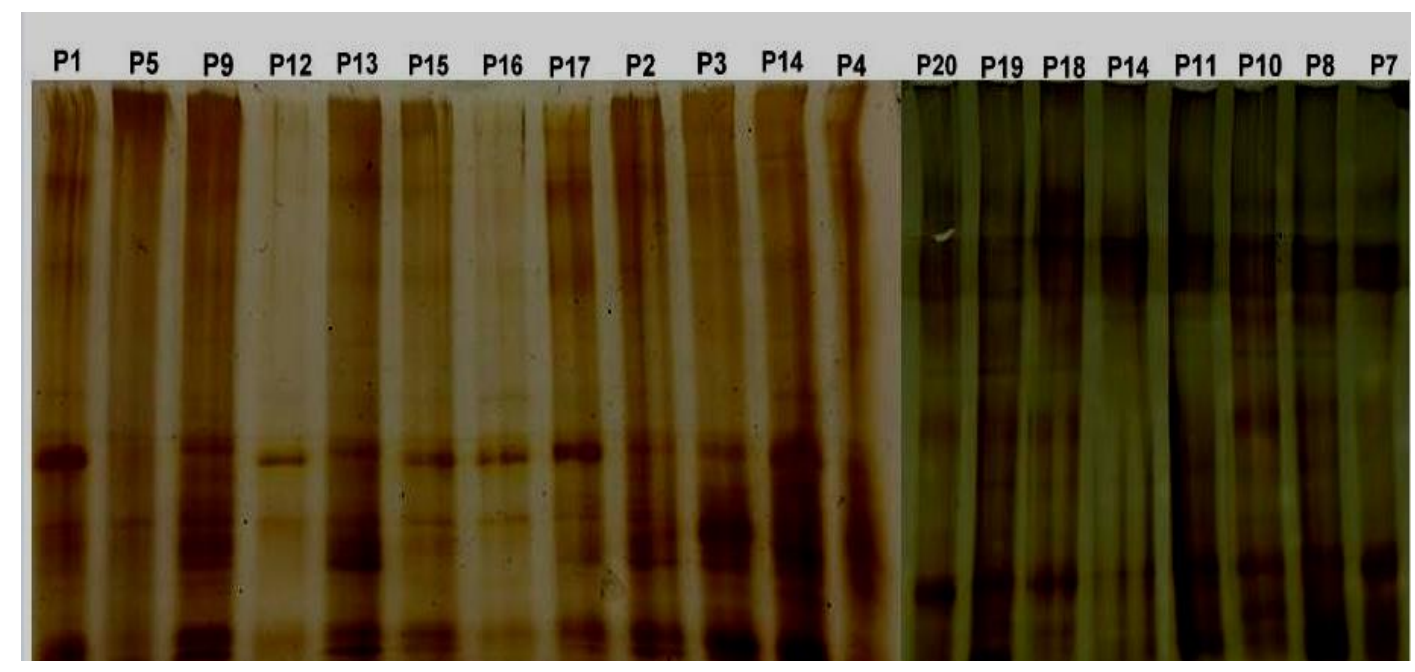


Fig.2 UPGMA of twenty carambola genotypes based on total seed protein profiles obtained by SDS-PAGE

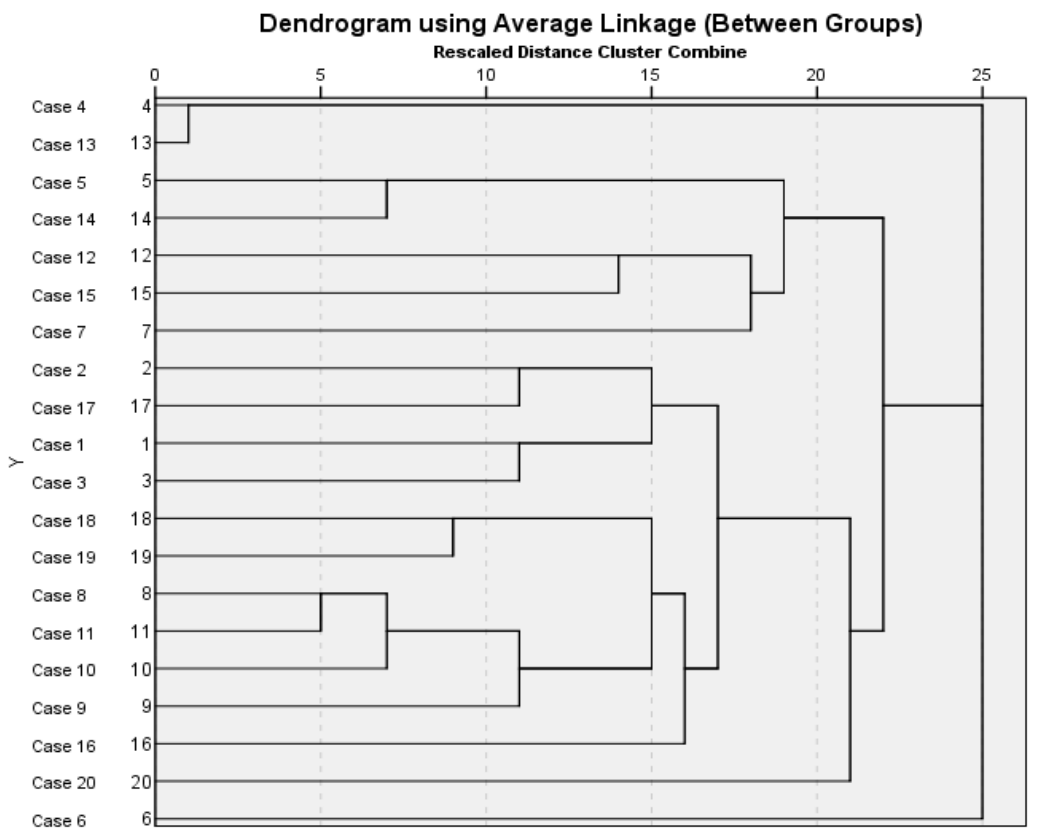

Fig.3 Diversity of carambola found in Arunachal Pradesh

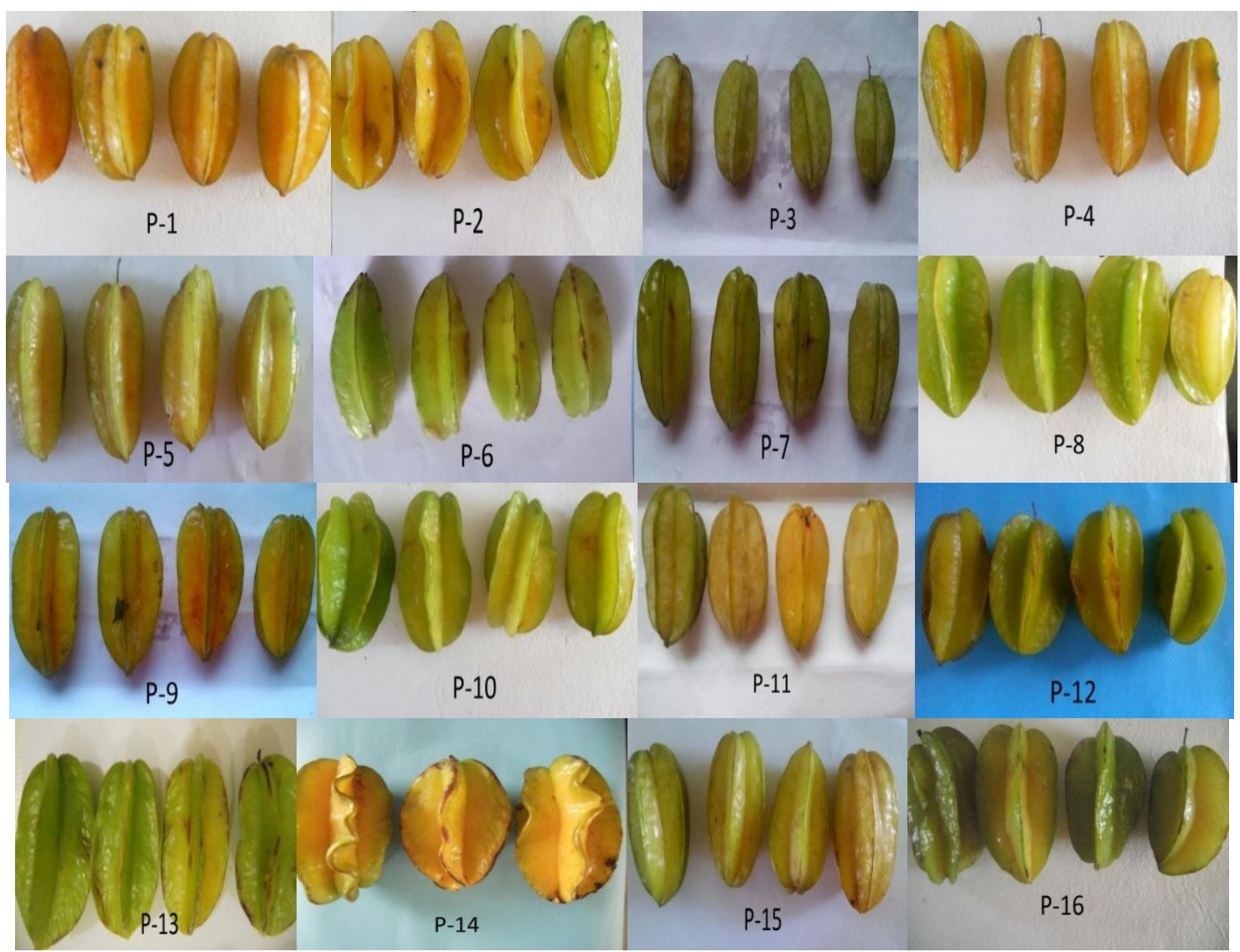


Table.1 Physical parameters among the selected genotypes based on descriptors

\begin{tabular}{|c|c|c|c|c|c|c|c|c|c|c|c|}
\hline Treatment & $\begin{array}{l}\text { Fruit } \\
\text { Weight } \\
\text { (g) }\end{array}$ & $\begin{array}{l}\text { Fruit } \\
\text { Diameter } \\
\text { (cm) }\end{array}$ & $\begin{array}{l}\text { Fruit } \\
\text { Length (cm) }\end{array}$ & $\begin{array}{l}\text { Fruit rib } \\
\text { length } \\
(\mathrm{cm})\end{array}$ & $\begin{array}{l}\text { Fruit rib } \\
\text { thickness } \\
\text { (cm) }\end{array}$ & $\begin{array}{l}\text { No. of } \\
\text { Seeds/ } \\
\text { Fruit }\end{array}$ & $\begin{array}{c}\text { Average } \\
\text { Weight } \\
\text { of } 10 \\
\text { Seed (g) }\end{array}$ & $\begin{array}{c}\text { Pedicel } \\
\text { Length } \\
\text { (cm) }\end{array}$ & $\begin{array}{l}\text { Pedicel } \\
\text { diamete } \\
\text { r(cm) }\end{array}$ & $\begin{array}{l}\text { Fruit } \\
\text { juice } \\
\text { content } \\
\text { per } \\
\text { Fruit } \\
\text { (ml) }\end{array}$ & $\begin{array}{l}\text { Productivit } \\
\text { y } \\
\text { (yield per } \\
\text { plant per } \\
\text { year) }\end{array}$ \\
\hline $\mathbf{P}_{1}$ & 100.00 & 4.93 & 7.90 & 1.80 & 1.40 & 2.00 & 0.56 & 4.17 & 0.25 & 32.00 & 125.00 \\
\hline $\mathbf{P}_{2}$ & 170.03 & 6.90 & 11.10 & 1.87 & 1.50 & 3.00 & 0.63 & 5.13 & 0.24 & 36.37 & 155.00 \\
\hline $\mathbf{P}_{3}$ & 90.03 & 5.40 & 8.13 & 2.00 & 1.43 & 3.33 & 0.67 & 4.40 & 0.22 & 30.00 & 108.33 \\
\hline $\mathbf{P}_{4}$ & 109.67 & 4.93 & 6.83 & 2.10 & 1.60 & 4.00 & 0.64 & 4.60 & 0.23 & 25.00 & 84.33 \\
\hline $\mathbf{P}_{5}$ & 90.03 & 4.07 & 6.87 & 2.10 & 1.83 & 4.33 & 0.73 & 4.37 & 0.23 & 25.67 & 95.00 \\
\hline $\mathbf{P}_{6}$ & 105.00 & 4.17 & 8.30 & 1.93 & 1.57 & 3.00 & 0.68 & 4.77 & 0.22 & 35.00 & 111.67 \\
\hline $\mathbf{P}_{7}$ & 112.00 & 5.03 & 10.27 & 2.10 & 1.30 & 3.67 & 0.63 & 4.87 & 0.21 & 32.00 & 115.00 \\
\hline $\mathbf{P}_{8}$ & 120.00 & 7.37 & 9.77 & 2.03 & 1.50 & 4.00 & 0.67 & 4.93 & 0.20 & 47.33 & 185.00 \\
\hline $\mathbf{P}_{9}$ & 99.77 & 5.37 & 8.20 & 2.20 & 1.73 & 3.33 & 0.60 & 3.90 & 0.18 & 34.67 & 165.00 \\
\hline $\mathbf{P}_{10}$ & 115.00 & 6.63 & 8.10 & 2.20 & 1.40 & 2.67 & 0.68 & 4.10 & 0.21 & 38.00 & 110.33 \\
\hline $\mathbf{P}_{11}$ & 130.03 & 4.13 & 10.27 & 2.30 & 1.57 & 3.33 & 0.73 & 4.07 & 0.19 & 43.33 & 115.00 \\
\hline $\mathbf{P}_{12}$ & 121.00 & 5.10 & 8.20 & 2.10 & 1.37 & 4.67 & 0.62 & 4.27 & 0.22 & 32.67 & 111.67 \\
\hline $\mathbf{P}_{13}$ & 118.13 & 5.37 & 8.30 & 1.73 & 1.70 & 2.67 & 0.69 & 4.53 & 0.23 & 34.33 & 111.00 \\
\hline $\mathbf{P}_{14}$ & 300.00 & 9.13 & 15.93 & 2.33 & 1.83 & 3.67 & 0.73 & 4.57 & 0.26 & 61.67 & 124.33 \\
\hline $\mathbf{P}_{15}$ & 130.97 & 6.13 & 7.07 & 1.53 & 1.40 & 2.67 & 0.60 & 4.00 & 0.24 & 41.67 & 112.33 \\
\hline $\mathbf{P}_{16}$ & 112.93 & 5.13 & 6.90 & 1.90 & 1.57 & 4.00 & 0.64 & 3.87 & 0.22 & 41.00 & 112.67 \\
\hline $\mathbf{P}_{17}$ & 152.90 & 5.60 & 11.30 & 1.80 & 1.53 & 3.33 & 0.76 & 4.03 & 0.23 & 33.00 & 118.33 \\
\hline $\mathbf{P}_{18}$ & 90.07 & 6.17 & 7.60 & 1.40 & 1.40 & 2.67 & 0.67 & 4.17 & 0.21 & 49.67 & 95.00 \\
\hline $\mathbf{P}_{19}$ & 98.00 & 4.43 & 7.40 & 1.50 & 1.53 & 4.00 & 0.62 & 4.20 & 0.18 & 26.00 & 162.67 \\
\hline $\mathbf{P}_{20}$ & 83.53 & 4.20 & 7.73 & 1.50 & 1.50 & 4.00 & 0.66 & 4.23 & 0.22 & 28.50 & 152.33 \\
\hline Mean & 122.46 & 5.51 & 8.81 & 1.92 & 1.53 & 3.42 & 0.66 & 4.36 & 0.26 & 36.39 & 123.50 \\
\hline SEm \pm & 1.38 & 0.07 & 0.07 & 0.04 & 0.02 & 0.20 & 0.01 & 0.06 & - & 0.48 & 1.69 \\
\hline CD 5\% & 3.94 & 0.21 & 0.19 & 0.11 & 0.07 & 0.56 & 0.02 & 0.17 & - & 1.38 & 4.85 \\
\hline
\end{tabular}


Table.2 Quality parameters of fruit based on descriptor of carambola

\begin{tabular}{|c|c|c|c|c|c|c|c|c|c|c|}
\hline Treatment & $\begin{array}{l}\text { TSS } \\
\left({ }^{\circ} \text { Brix) }\right.\end{array}$ & $\begin{array}{l}\text { Fruit } \\
\text { Oxalic acid } \\
(\%)\end{array}$ & $\begin{array}{l}\text { Fruit } \\
\text { titratable } \\
\text { acid }(\%)\end{array}$ & $\begin{array}{l}\text { Vitamin C } \\
(\mathrm{mg} / 100 \mathrm{~g})\end{array}$ & pH & $\begin{array}{l}\text { Non- } \\
\text { reducing } \\
\text { Sugars }(\%)\end{array}$ & $\begin{array}{l}\text { Reducing } \\
\text { sugars }(\%)\end{array}$ & $\begin{array}{l}\text { Total } \\
\text { Sugars } \\
(\%)\end{array}$ & $\begin{array}{l}\text { Fruit } \\
\text { firmness } \\
\text { (kgf) }\end{array}$ & $\begin{array}{l}\text { Shelf life } \\
\text { In days }\end{array}$ \\
\hline $\mathbf{P}_{1}$ & 6.20 & 0.02 & 0.57 & 48 & 3.73 & 0.09 & 6.23 & 6.63 & 2.20 & 12.00 \\
\hline $\mathbf{P}_{2}$ & 7.33 & 0.01 & 0.27 & 42 & 4.63 & 0.08 & 8.50 & 9.07 & 1.63 & 12.00 \\
\hline $\mathbf{P}_{3}$ & 8.07 & 0.01 & 0.37 & 47 & 4.50 & 0.07 & 3.20 & 3.40 & 1.59 & 12.00 \\
\hline $\mathbf{P}_{4}$ & 6.03 & 0.03 & 0.88 & 51 & 2.53 & 0.07 & 4.30 & 4.57 & 2.27 & 13.33 \\
\hline $\mathbf{P}_{5}$ & 5.23 & 0.01 & 0.37 & 41 & 3.60 & 0.07 & 7.30 & 7.70 & 1.51 & 12.00 \\
\hline $\mathbf{P}_{6}$ & 5.07 & 0.02 & 0.49 & 45 & 3.57 & 0.07 & 9.73 & 10.50 & 1.56 & 13.33 \\
\hline $\mathbf{P}_{7}$ & 7.30 & 0.01 & 0.30 & 41 & 2.43 & 0.08 & 8.67 & 9.10 & 1.53 & 11.33 \\
\hline $\mathbf{P}_{8}$ & 8.50 & 0.01 & 0.32 & 31 & 4.03 & 0.07 & 7.60 & 8.23 & 2.43 & 12.00 \\
\hline $\mathbf{P}_{9}$ & 8.53 & 0.35 & 0.94 & 68 & 4.10 & 0.07 & 5.70 & 5.97 & 1.49 & 12.67 \\
\hline $\mathbf{P}_{10}$ & 5.83 & 0.16 & 0.38 & 30 & 3.47 & 0.05 & 5.00 & 5.23 & 2.35 & 10.67 \\
\hline $\mathbf{P}_{11}$ & 14.97 & 0.16 & 0.20 & 47 & 2.60 & 0.07 & 11.93 & 12.80 & 2.30 & 11.33 \\
\hline $\mathbf{P}_{12}$ & 5.03 & 0.03 & 0.78 & 42 & 3.80 & 0.06 & 5.93 & 6.30 & 2.27 & 13.33 \\
\hline $\mathbf{P}_{13}$ & 6.07 & 0.03 & 0.08 & 38 & 3.80 & 0.07 & 3.60 & 3.97 & 2.31 & 12.67 \\
\hline $\mathbf{P}_{14}$ & 9.50 & 0.01 & 0.38 & 30 & 2.40 & 0.03 & 8.53 & 9.27 & 1.66 & 12.00 \\
\hline $\mathbf{P}_{15}$ & 6.13 & 0.02 & 0.57 & 45 & 2.50 & 0.08 & 7.93 & 8.23 & 1.78 & 12.67 \\
\hline $\mathbf{P}_{16}$ & 5.73 & 0.03 & 0.75 & 51 & 3.53 & 0.07 & 4.60 & 4.73 & 2.29 & 13.33 \\
\hline $\mathbf{P}_{17}$ & 6.10 & 0.05 & 1.22 & 25 & 2.73 & 0.14 & 7.47 & 8.00 & 2.38 & 14.00 \\
\hline $\mathbf{P}_{18}$ & 8.03 & 0.01 & 0.40 & 38 & 3.73 & 0.06 & 9.07 & 9.17 & 2.29 & 11.33 \\
\hline $\mathbf{P}_{19}$ & 7.87 & 0.02 & 0.48 & 50 & 3.37 & 0.05 & 8.73 & 8.93 & 1.45 & 12.67 \\
\hline $\mathbf{P}_{20}$ & 8.03 & 0.10 & 0.25 & 33 & 3.20 & 0.08 & 8.40 & 3.97 & 1.55 & 11.33 \\
\hline Mean & 7.28 & 0.05 & 0.50 & 63 & 3.41 & 0.08 & 7.12 & 7.29 & 1.94 & 12.30 \\
\hline SEm \pm & 0.08 & 0.0034 & 0.0012 & 0.17 & 0.03 & - & 0.10 & 0.07 & 0.03 & 0.36 \\
\hline C.D. 5\% & 0.16 & 0.0096 & 0.0034 & 0.01 & 0.08 & - & 0.27 & 0.14 & 0.08 & 1.01 \\
\hline
\end{tabular}


On content of titratable acidity the minimum acidity was recorded in $\mathrm{P}_{13}(0.08 \%)$ whereas maximum titratable acidity was observed in $\mathrm{P}_{17}(1.22 \%)$. In this regard, Das and Bal (2010) reported that acidity ranged from 0.47 $0.87 \%$. Besides, Chadha (2013) also reported that acidity of carambola ranged from $0.4 \%$ to $1 \%$. The observed values on firmness of fruit varied significantly among different genotypes. $\mathrm{P}_{17}$ was recorded highest (2.43 $\mathrm{kgf})$ followed by $\mathrm{P}_{8}(2.38 \mathrm{kgf})$ whereas lowest was recorded in $\mathrm{P}_{19}(1.45 \mathrm{kgf})$ with the average value of $1.94 \mathrm{kgf}$. Omar and Matjafri (2013) reported that firmness of carambola ranged from 1.5-8 kgf. Different selected genotypes showed significant variation for fruit $\mathrm{pH}$ value and the observed value varied from 2.4 to 4.63. Minimum $\mathrm{pH}$ value was found in $\mathrm{P}_{14}$ (2.4) and maximum in $\mathrm{P}_{2}$ (4.63) with average mean value 3.41. In this regard Watson et al., (1988) found that the $\mathrm{pH}$ content of carambola ranged from 2.5-5.0 which is in consonance with the present finding.

Different selected genotypes showed significant variation for ascorbic acid content and varied from $25 \mathrm{mg} / 100 \mathrm{~g}$ in $\mathrm{P}_{17}$ to $68 \mathrm{mg} /$ $100 \mathrm{~g}$ in $\mathrm{P}_{9}$. Genotype $\mathrm{P}_{19}(50 \mathrm{mg} / 100 \mathrm{~g})$ was statistically at par with both $\mathrm{P}_{4}$ and $\mathrm{P}_{16}(51 \mathrm{mg} /$ $100 \mathrm{~g}$ ). The vitamin $\mathrm{C}$ content of genotype $\mathrm{P}_{9}$ was found to be highest. In this regard Lim and Lee (2013) recorded that the vitamin C contents of carambola was $1.56 \mathrm{~g}$ per $100 \mathrm{~g}$ which is a contrast to the present finding. Ali and Jafaar (2013) also reported that vitamin C content of carambola was 38- $40.2 \mathrm{mg}$ per $100 \mathrm{~g}$ in 13 weeks of fruit set. The observed data on total sugar content of fruit revealed significant variation among genotypes and varied from $3.4 \%$ in $\mathrm{P}_{3}$ to $12.8 \%$ in $\mathrm{P}_{11}$ with an average value of $7.29 \%$. Genotypes $\mathrm{P}_{11}$ recorded to have the highest content of total sugar followed by $\mathrm{P}_{6}(10.5 \%), \mathrm{P}_{14}(9.27 \%)$, $\mathrm{P}_{18}(9.17 \%)$ and $\mathrm{P}_{7}(9.1 \%)$. Watson et al., (1988) found out that total sugar content ranged from $3.5-11 \%$ in $100 \mathrm{~g}$ which is in consonance with the present study. The observed values on reducing sugar content of fruit varied significantly which ranged from $3.2 \%$ in $\mathrm{P}_{3}$ to $11.93 \%$ in $\mathrm{P}_{11}$ with an average of $7.12 \% . \mathrm{P}_{11}$ is followed by $\mathrm{P}_{6}(9.73 \%), \mathrm{P}_{18}$ (9.07\%) and $\mathrm{P}_{18}(8.73 \%)$. Das and Bal (2010) reported reducing sugar carambola fruit ranged from $2.79-4.58 \%$.

The observed values on non-reducing sugar content of the fruits were non-significant among genotypes in which average reducing sugar ranged from $0.03-0.14 \%$. Das and Bal (2010) reported that non- reducing sugar of the carambola ranged from $2.25-2.36 \%$. At room temperature shelf life of selected genotypes of carambola varied significantly which ranged from 10.67 days in $\mathrm{P}_{10}$ to 14 days in $\mathrm{P}_{17}$ with the average of 12.30 days. Rathod (2011) reported that carambola treated with 200 gauge highly density polyethylene without ventilation can store upto for 21 days.

\section{Genotype characterization through seed protein profiles}

Sodium Dodecyl Sulphate Polyacrylamide Gel Electrophoresis (SDS-PAGE) is an economical, simple and extensively used biochemical technique for describing the seed protein diversity of crop germplasm (Fufa et al., 2005; Iqbal et al., 2005). Seed protein variants have been observed to be the most widely used biochemical genetic markers during the last quarter century. Its success depends upon the polymorphism of seed and seedling proteins and the fact that these proteins represent primary gene products and are largely unaffected by the environmental interactions (Smith and Smith, 1992). Caution should be taken in interpreting darkness and thickness as the kind of variation may be due to the lack of separation on the gels of several proteins having similar migration rates and studies are required to estimate the number of 
genes causing quantitative variation in seed protein bands (Ladizinsky and Haymowitz, 1979). SDS-PAGE was carried out to determine the protein banding patterns of 20 carambola genotypes. The genotypes showed considerable variation in band number of protein in present investigation which ranged from 14-38. Among the genotypes $\mathrm{P}_{3}$ showed maximum number (38) of protein bands while the minimum number (14) of bands was present in genotype $\mathrm{P}_{6}$ and $\mathrm{P}_{12}$. Cluster analysis utilizing SDS-PAGE banding pattern produced a dendrogram depicting clear separation of genotypes. Difference index generated by SDS-PAGE analysis in the germplasm under study range from 0.00 to 0.95. Values of difference index coefficient matrix suggested least difference index of genotype $\mathrm{P}_{4}$ with $\mathrm{P}_{13}(0.11)$ while genotype $\mathrm{P}_{4}$ was found to have maximum difference index with genotype $\mathrm{P}_{6}$ as evident by coefficient value 0.95 . Thus, SDS-PAGE marker data provided more sub groupings and revealed higher amount of diversity as compared to morphological data analysis. It is evident from the present study that genetic relationship estimated from protein banding pattern enhanced the resolution of diversity and thus provided a better picture of variability as compared to morphological markers. Although SDS-PAGE analysis could show discrete variation among few genotypes of carambola under study, this protein marker should be applied in future to more number of genotypes to arrive at a reasonable conclusion. Therefore, seed protein electrophoresis could be proved to be a successful technique in certain cases to distinguish morphologically indistinguishable genotypes (Fig. 1-3).

Based on the results obtained from the present investigation, it can be concluded that, selected carambola genotypes exhibited noticeable variation in the morphological and biochemical characteristics. The genotypes $\mathrm{P}_{8}$ gave maximum yield (185 $\mathrm{kg}$ per tree per year), $\mathrm{P}_{11}$ highest TSS $\left(14.95^{\circ} \mathrm{Brix}\right), \mathrm{P}_{1}$ lowest seed (2), $\mathrm{P}_{9}$ highest vitamin $\mathrm{C}(68 \mathrm{mg} / 100 \mathrm{~g})$ and $\mathrm{P}_{14}$ gave highest fruit weight $(300 \mathrm{~g})$. Thus, these findings illustrated the usefulness of physic-chemical characterization and biochemical marker as a tool for the genetic diversity evaluation in carambola.

\section{Acknowledgements}

The authors like to render gratefulness to the College of Horticulture \& Forestry, Central Agricultural University for allowing the research work for this under ultized fruit crop.

\section{References}

Ali, S.H. and Jafaar, M.Y., 1992. Effect of harvest maturity on physical and chemical characteristics of carambola (Averrhoa carambola L.). N. Z. J. Crop Hortic. Sci., 20(2): 133-136.

Bhaskar, B. and Shantaram, M., 2013. Morphological and biochemical characteristic of Averrhoa fruits. Int. J. Pharm. Chem. Biol. Sci., 3(3): 924-928.

Chadha, K.L., 2013. Carambola. In: Handbook of horticulture. Directorate of knowledge Management in Agriculture ICAR publishing house, Krish Anusandhan Bhavan, Pusa New Delhi, pp.159.

Crane, J.H., 1994. The carambola (star fruit). Fact Sheet HS-12. Florida Cooperative Extension Service, IFAS, University of Florida, Gainesville, FL. pp.1-5.

Das, J.N. and Bal, S., 2010. Studies on physico-chemical traits of local carambola germplasm. India. J.Hort., 67(3):391-393

Fufa, H., Baenziger, P.S., Beecher, B.S., Dweikat, I., Graybosch, R.A. and Eskridge, K.M., 2005. Comparison of phenotypic and molecular marker based classifications of hard red winter wheat 
cultivars. Euphytica, 145:133-146.

Gheewala, P., Kalaria. P., Chakraborty, M. and Kamath, J.V., 2012. Phytochemical and pharmacological profile of Averrhoa carambola Linn: An overview. Int. Res. J. Pharam., 3(1):8892.

Goenaga, R., 2007. Yield and fruit quality traits of carambola cultivars grown at three locations in Puerto Rico. Hortic. Technol., 17(4): 604-607

Haick, I. (1952). An Fac. Farme Odontol Univ. Sao Paulo, 10: 125-133.

Iqbal, S.H., Ghafoor, A. and Ayub, N. (2005). Relationship between SDS-PAGE markers and Ascochyta blight in chickpea. Pakistan J. Bot., 37: 87-96.

Ladizinski, G. and Hymowitz, T., 1979. Seed protein electrophoresis in taxonomic and evolutionary studies. Theor. Appl. Genet., 54:145-151.

Laemmli, U.K., 1970. Cleavage of structural proteins during the assembly of the head of bacteriophage T4. Nature, 227:680685.

Lewis, Y.S., Dwarakanath, C.T. and Johar, D.S., 1954. Acids and sugars in the Kamrakh fruit, Averrhoa carombola Linn. Curr. Sci., 23: 54-55.

Lowry, O.H., Rosebrough, N.J., Farr, A.L. and Randall, R.J., 1951. Protein measurement with the Folin phenol reagent. J. Biol. Chem., 193:265-275

Morton, J. (1987). Carambola En: Fruits of warm climates. South. Book Ser., Miami, FL.

Narain, N., Bora, P.S., Holschuh, H.J. and Vasconcelos, M.A.D., 2001. Physical and chemical composition of carambola fruit (Averrhoa carambola L.) at three different stages of maturity. J. Food., 3(3): 144-148

Omar, A.F. and Matjafri, M.Z., 2013. Specialized optical fiber sensor for nondestructive instrinsic quality measurement of Averrhoa carambola. Photonic sensors., 3(3):273-282

Rathod, A., Shoba, H. And Chinanand, D.V., 2011. A study on shelf life extension of carambola. Int. J. Sci. Eng. Res., 2(9): $1-5$.

Ray, P.K., 2002. Carambola. In: Breeding Tropical and Subtropical Fruits. Published by Narosa Publishing House, pp.307-315.

Shui, G. and Leong, L.P., 2004. Analysis of polyphenolic antioxidants in star fruit using liquid chromatography and mass spectrometry. J. Chromatogr., 1022 (12): 67-75.

Singh, A.K. Singh, B.P. and Rajput, C.B.S., 1990. Studies on correlation between the physico-chemical properties of fruit in mango (Mangifera indica L.). Res. Dev. Rep., 7: 12 - 14.

Singh, S.R. Phurailatpam, A.K. Wangchu, L. Ngangbam, P. and Chanu, T.M., 2014. Traditional medicinal knowledge of underutilized minor fruits as medicine in Manipur. Int. J. Agric. Sci., 4 (8): 241-247.

Smith, J.S.C. and Smith, O.S., 1992. Fingerprinting in crop varieties. $A d v$. Agron., 47: 85-140.

Watson, B.J., George, A.P., Nissen, R.J. and Brown, B.I., 1988. Carambola: a star on the horizon. Qld. Agric. J., 114: 45-54.

\section{How to cite this article:}

Rebica Padun and Singh, S.R. 2018. Evaluation of Genetic Diversity of Carambola (Carambola averrhoa L.) in Arunachal Pradesh, India. Int.J.Curr.Microbiol.App.Sci. 7(02): 2729-2738. doi: https://doi.org/10.20546/ijcmas.2018.702.332 